\title{
Hubungan Antara Tingkat Pendidikan dan Pendapatan Karyawan dengan Pengetahuan dan Sikap Keamanan Pangannya pada Tempat Makan di DKI Jakarta
}

\section{(Correlation between Education and Net Income of Employees with Their Food Safety Knowledges and Attitudes at Food Stalls in DKI Jakarta)}

\author{
Arie Norman Riandi ${ }^{1}$, Winiati Pudji Rahayu ${ }^{2,3^{*}}$, Siti Nurjanah ${ }^{2,3}$
}

(Diterima Juli 2020/Disetujui November 2020)

\begin{abstract}
ABSTRAK
Keamanan pangan (KP) merupakan salah satu aspek penting dalam perilaku konsumsi, khususnya bagi para karyawan di kantor. Pengetahuan dan juga kepedulian yang kurang akan hal ini dapat menyebabkan keracunan pangan sehingga membahayakan kesehatan dan menurunkan tingkat produktivitas karyawan. Penelitian ini bertujuan untuk menggambarkan tingkat pengetahuan dan sikap para karyawan pada KP tempat makan serta preferensi tempat makan di lingkungan perkantoran. Selain itu, juga ingin diketahui efektivitas sumber informasi KP dan peran pemerintah dalam edukasi KP serta pengawasan keamanan tempat makan. Survei yang dilakukan pada 405 orang responden karyawan kantor DKI Jakarta dilakukan secara daring (online). Data yang dikumpulkan kemudian dianalisis secara statistik menggunakan program SPSS. Hasil penelitian menunjukkan bahwa karakteristik profil karyawan, seperti tingkat pendidikan dan tingkat penghasilan, berpengaruh pada tingkat pengetahuan dan sikap KP di tempat makan. Sebanyak 87,7\% karyawan memiliki tingkat pengetahuan KP yang baik dan sebanyak 64,7\% karyawan memiliki sikap yang baik terhadap KP di tempat makan. Hasil uji korelasi Spearman menunjukkan tingkat pengetahuan dan sikap KP di tempat makan berkorelasi dengan tingkat pendidikan dan tingkat penghasilan karyawan. Karyawan kantor sebagian besar $(37,8 \%)$ memilih kantin untuk tempat makan di kantor dan sebagian memilih warung makan $(16,0 \%)$ dan restoran $(10,1 \%)$. Media informasi yang dinilai cukup efektif untuk menyebarkan informasi KP adalah media sosial, namun efektivitasnya masih perlu terus ditingkatkan.
\end{abstract}

Kata kunci: karyawan kantor, keamanan pangan, pengetahuan, perilaku konsumsi, sikap

\section{ABSTRACT}

Food safety is an important aspect of consumption behavior, especially for employees in the office. Lack of food safety knowledge and awareness can endanger the health and reduce the productivity of employee. This study aims to describe the level of food safety knowledge and attitudes of employees at food stalls as well as their preferences for lunch at office environment, determine the effectiveness of information media as a source of food safety information and also the role of the government in food safety education and food safety supervision at food stalls. This study used an online questionnaire with 405 respondents who work in the DKI Jakarta. The data collected were analyzed statistically using the SPSS program. The results showed that the characteristics of the employees, such as education level and nett income level, had an effect on the food safety knowledge level and food safety attitudes at the food stalls. Most of employees (87,7\%) have a good level of food safety knowledge and $67,7 \%$ of employees also have a good level of food safety attitude at food stalls. The results of the Spearman correlation test showed that the level of food safety knowledge and attitude at food stalls was correlated with the level of education and nett income. Most of the employees $(37,8 \%)$ choose the canteen as a place to eat in the office and some choose food stalls $(\mathbf{1 6 , 0} \%)$ and restaurants $(\mathbf{1 0 , 1} \%)$. Information media considered effective enough for spreading the information of food safety according to employees was social media.

Keywords: attitudes, consumption behaviour, employees, food safety, knowledge

1 Sekolah Pascasarjana, Program Studi Magister Teknologi Pangan, Institut Pertanian Bogor, Kampus IPB Darmaga, Bogor 16680

2 Departemen IImu dan Teknologi Pangan, Fakultas Teknologi Pertanian, Institut Pertanian Bogor, Kampus IPB Darmaga, Bogor 16680

3 SEAFAST Center, Institut Pertanian Bogor, Kampus IPB Darmaga, Bogor 16680

* Penulis Korespondensi: E-mail: wpr@apps.ipb.ac.id

\section{PENDAHULUAN}

Keamanan pangan (KP) merupakan aspek penting dalam kehidupan sehari-hari, khususnya dalam hal perilaku konsumsi pangan. Pengetahuan dan juga kepedulian yang kurang tentang hal keamanan pangan ini dapat membahayakan kesehatan konsumen dan dapat juga menjadi salah satu penyebab keracunan pangan. Selama tahun 2018, terdapat 56 laporan Kejadian Luar Biasa (KLB) keracunan pangan yang 
disampaikan oleh Balai Besar Pengawas Obat dan Makanan (BB-POM) kepada BPOM melalui aplikasi Sistem Informasi Masyarakat Keracunan (SPIMKER). Jumlah orang yang terpapar dari 56 KLB keracunan pangan tersebut adalah sebanyak 2.897 orang dan 1.661 orang di antaranya sakit (attack rate sebesar $55,60 \%$ ). Berdasarkan tempat/lokasi/lokus KLB keracunan pangan, tempat tinggal menduduki urutan pertama, yaitu sebanyak 21 kejadian (37,50\%) disusul oleh lembaga pendidikan sekolah dasar (SD)/ madrasah ibtidaiyah (MI) dengan 16 kejadian $(28,57 \%)$, dan sebanyak lima kejadian $(8,92 \%)$ di kantor/ pabrik (BPOM 2019).

Gejala keracunan pangan yang paling sering timbul adalah penyakit diare yang disebabkan oleh kontaminasi bakteri atau virus. Kontaminasi bakteri dan virus ini pada umumnya disebabkan oleh perhatian yang kurang akan kebersihan pada saat pengolahan pangan ataupun pada saat penyajian. Data Riset Kesehatan Dasar (Riskesdas) pada tahun 2018 menyebutkan angka penyakit di Daerah Khusus Ibukota (DKI) Jakarta memiliki prevalensi diare sebesar 5,7\%. Di wilayah DKI Jakarta, pada tahun 2018 dilaporkan terdapat lebih dari 225 ribu penderita diare pada semua umur (Dinkes DKI Jakarta 2019).

Keracunan pangan juga dapat menimbulkan kerugian ekonomi, seperti harus mengeluarkan biaya untuk berobat ataupun perawatan selama di rumah sakit. Rahayu et al. (2016) melaporkan bahwa estimasi kerugian ekonomi yang ditimbulkan akibat keracunan pangan mencapai sekitar US \$ 78 juta. Berbagai upaya tambahan diperlukan dari berbagai pihak untuk mengatasi masalah KP agar dapat meminimalisir kerugian yang timbul di masa yang akan datang.

Pegawai kantor atau karyawan menghabiskan sebagian besar waktunya di lingkungan kantor mereka (sekitar 8-9 jam sehari). Kementerian Kesehatan Republik Indonesia (Kemenkes RI) pada saat ini juga sudah menyadari pentingnya mewujudkan lingkungan kerja yang aman dan sehat melalui Peraturan Menteri Kesehatan (Permenkes) No. 48 tahun 2016 tentang standar keselamatan dan kesehatan kerja perkantoran, yang menyebutkan bahwa salah satu yang harus diperhatikan adalah pangan. Pangan yang tersedia di lingkungan perkantoran bagi tenaga kerja/pekerja harus dikelola dengan baik, aman, dan sehat agar tidak menyebabkan gangguan kesehatan dan bermanfaat bagi tubuh (Kemenkes, 2016).

Tingkat pendidikan para karyawan kantor sangat memengaruhi kesadaran mereka akan KP yang menjadi dasar bagi para karyawan dalam memilih jajanan pangan yang aman dan sehat di sekitar kantornya. Penelitian Vyas \& Kushwaha (2017) melaporkan bahwa tingkat pendidikan seseorang memberikan pengaruh yang signifikan pada kesadaran akan KP jajanan. Selain tingkat pendidikan seseorang, tingkat penghasilan juga memengaruhi kesadaran seseorang akan KP yang dikonsumsinya. Menurut Alimi et al. (2016), sikap dan perilaku konsumen dalam memilih jajanan pangan bervariasi dan sebagian ditentukan oleh faktor ekonomi.

Data karyawan di DKI Jakarta pada bulan Agustus 2019 didominasi oleh mereka yang berpendidikan Sekolah Menengah Umum (SMU). Jumlah pekerja dengan tingkat pendidikan sekolah menengah umum sebanyak 2.241.151 orang atau sebesar 46,33\% dari total penduduk yang bekerja di wilayah DKI Jakarta (BPS DKI Jakarta 2020). Pemerintah Provinsi DKI Jakarta menetapkan Upah Minimum Provinsi (UMP) pada tahun 2020 sebesar Rp4.276.349 (Pergub DKI Jakarta 2019). Tingkat pendidikan sebagian besar karyawan di DKI Jakarta yang cukup tinggi dan UMP yang cukup besar diperkirakan akan berpengaruh pada pengetahuan dan sikap atas KP di tempat makan di sekitar kantor mereka. Akan tetapi, karyawan kantor sering kali tidak memilih tempat makan dengan baik dengan alasan keterbatasan pilihan menu, pilihan tempat makan, maupun waktu makan siang. Hal ini dapat menyebabkan karyawan menjadi sakit akibat keracunan pangan bila pangan yang dikonsumsi tercemar mikrob sehingga menurunkan produktivitas karyawan.

Penelitian ini bertujuan untuk menggambarkan tingkat pengetahuan dan sikap para karyawan terhadap KP tempat makan serta preferensi tempat makan siang di lingkungan perkantoran, menentukan efektivitas media informasi sebagai sumber informasi KP dan juga peran pemerintah dalam edukasi KP serta pengawasan keamanan tempat makan.

\section{METODE PENELITIAN}

\section{Bahan dan Alat}

Penelitian ini menggunakan daftar pertanyaan kuesioner yang dibuat di aplikasi kuesioner daring (online) via situs web: www.surveymonkey.com sebagai bahan untuk pengumpulan data. Alat yang digunakan sebagai media untuk mengisi kuesioner responden adalah ponsel pintar (smartphone) dan komputer/laptop. Program aplikasi Microsoft Excel 2016 dan Statistical Program for Social Science (SPSS) versi 25 digunakan sebagai alat untuk mengolah data.

\section{Tahapan Penelitian}

Penelitian ini dilakukan dalam lima tahap seperti diuraikan berikut ini. Penelitian ini dilakukan selama 11 bulan bertempat di wilayah DKI Jakarta, dalam lima tahap.

\section{Penyusunan Kuesioner (modifikasi Totelesi 2011)}

Kuesioner disusun menjadi lima blok pertanyaan untuk mendapatkan informasi mengenai profil responden (pertanyaan nomor 1-10), tingkat pengetahuan KP responden (pertanyaan nomor 1120), sikap responden terhadap KP di tempat makan (pertanyaan nomor 31-40), preferensi responden dalam pemilihan tempat makan (pertanyaan nomor 
41-50), dan penilaian responden atas sumber informasi KP yang efektif serta peran pemerintah dalam pengawasan dan edukasi KP (pertanyaan nomor 51-55). Daftar pertanyaan disusun dalam pertanyaan tertutup yang mudah dipahami oleh para responden. Daftar pertanyaan untuk pengetahuan KP responden menggunakan modifikasi pertanyaan kuesioner pada penelitian Totelesi (2011)

\section{Penetapan Responden (Sevilla et al. 2007)}

Responden ditentukan secara purposive, dengan faktor inklusi bahwa responden adalah karyawan yang bekerja di wilayah Provinsi DKI Jakarta dan faktor eksklusi adalah bahwa responden bukan karyawan atau karyawan yang berkantor di luar wilayah Provinsi DKI Jakarta. BPS DKI Jakarta pada tahun 2019 menyebutkan bahwa jumlah penduduk DKI Jakarta yang bekerja sebanyak 4.836.977 orang (BPS DKI Jakarta 2020). Jumlah minimal sampel yang harus diambil ditentukan menurut rumus Slovin (Sevilla et al. 2007) sehingga diperoleh jumlah minimal sebanyak 400 responden sesuai perhitungan berikut:

$$
n=\frac{N}{1+N \alpha^{2}}=\frac{4.836 .977}{1+4.836 .977(0,05)^{2}}=399,96 \sim 400
$$

\section{Keterangan:}

$n=$ Jumlah sampel minimal

$N=$ Ukuran populasi (jumlah penduduk usia kerja di DKI Jakarta)

$\alpha=$ Arah signifikansi (menggunakan taraf signifikansi $5 \%)$

\section{Uji Coba Kuesioner (Riadi 2015; Nurgiyantoro et al. 2015)}

Uji Coba Kuesioner (Riadi 2015; Nurgiyantoro et al. 2015). Daftar pertanyaan tentang pengetahuan KP dan sikap responden terhadap KP di tempat makan yang sudah disusun kemudian diuji validitas dan reliabilitasnya kepada 50 responden. Setelah didapat nilai yang diperoleh dari tiap responden tersebut kemudian ditabulasikan dan dihitung nilai korelasinya berdasarkan persamaan korelasi Pearson (product moment) seperti pada persamaan berikut ini (Riadi 2015).

$$
r_{x y}=\frac{n(\Sigma X Y)-(\Sigma X)(\Sigma Y)}{\sqrt{\left\{n \Sigma X X^{2}-(\Sigma X)^{2}\right\}\left\{n \Sigma Y^{2}-(\Sigma Y)^{2}\right.}}
$$

Keterangan:

$r_{x y} \quad=$ Koefisien korelasi antara $\mathrm{X}$ dengan $\mathrm{Y}$

$\Sigma X=$ Jumlah total data variabel $X$

$n \quad=$ Jumlah sampel

$\Sigma Y=$ Jumlah total data variabel $Y$

$\sum X Y=$ Jumlah total data $X Y$

Setiap pertanyaan memiliki nilai korelasinya masing-masing yang kemudian hasilnya dibandingkan dengan angka kritis pada tabel korelasi. Nilai korelasi yang lebih tinggi dari angka kritis pada tabel korelasi menunjukkan bahwa pertanyaan/pernyataan tersebut signifikan dan memiliki validitas konstruk. Masingmasing pertanyaan yang sudah valid berdasarkan uji validitas, kemudian dilanjutkan dengan uji reliabilitas. Nilai reliabilitas diperoleh dengan uji Alpha Cronbach menggunakan persamaan berikut ini (Nurgiyantoro et al. 2015).

$$
r=\frac{k}{k-1}\left(1-\frac{\sum \sigma i^{2}}{\sigma^{2}}\right)
$$

Keterangan:

$$
\begin{array}{ll}
r & =\text { Koefisien reliabilitas yang dicari } \\
k & =\text { Jumlah butir pertanyaan (soal) } \\
\sigma i^{2} & =\text { Varian butir pertanyaan ke- } n \\
\sigma^{2} & =\text { Varian skor tes }
\end{array}
$$

Nilai korelasi Alpha Cronbach yang lebih tinggi dari angka kritis pada tabel korelasi menunjukkan bahwa pertanyaan yang digunakan pada kuesioner tersebut reliabel.

\section{Pelaksanaan dan Penyebaran Kuesioner (modifikasi Prawira et al. 2016)}

Survei dilaksanakan dengan menyebarkan kuesioner melalui media internet. Penelitian ini memodifikasi penyebaran kuesioner dari penelitian Prawira et al. (2016) yang menggunakan jasa ketiga, yaitu Jajak Pendapat App (JakPat App), penyebaran kuesioner dilakukan secara daring (online) dengan menyebarkan link kuesioner yang sudah dibuat via web: surveymokey.com melalui media sosial, seperti Whatsapp untuk kemudian diisi secara mandiri oleh para responden.

\section{Rekap Data dan Analisis Data (Anggitasari et al. 2014, Prawira et al. 2016)}

Pengolahan data hasil dari pertanyaan mengenai pengetahuan dan sikap KP di tempat makan para responden dihitung dengan menjumlahkan skor (jawaban benar diberi skor 1 dan jawaban salah diberi skor 0). Jumlah jawaban benar dari setiap responden dipersentasikan untuk diklasifikasikan ke dalam dua kategori, yakni pengetahuan/sikap responden dikatakan baik apabila skor $\geq 70 \%$ dan dikatakan kurang baik apabila skor $<70 \%$ (Anggitasari et al. 2014).

Data profil responden seperti tingkat pendidikan dan penghasilan per bulan dilihat keterkaitannya dengan pengetahuan dan sikap KP di tempat makan dengan menggunakan uji korelasi. Uji korelasi dilakukan dengan menggunakan uji Spearman sesuai dengan jenis data yang dikorelasikan (Prawira et al. 2016). Uji Spearman menggunakan persamaan berikut ini. 


$$
r h o=1-\frac{6 \sum D^{2}}{N\left(N^{2}-1\right)}
$$

Keterangan:

$$
\begin{array}{ll}
\text { rho } & =\text { Koefisien korelasi Spearman } \\
N & =\text { Jumlah sampel/kelompok } \\
D & =\text { Perbedaan skor antardua kelompok } \\
& \text { pasangan }
\end{array}
$$

\section{HASIL DAN PEMBAHASAN}

\section{Validitas dan Reliabilitas Kuesioner}

Validitas dan reliabilitas kuesioner merupakan salah satu aspek penting untuk menunjukkan keakuratan dan konsistensi survei/kuesioner. Validitas menjelaskan seberapa baik data yang dikumpulkan yang mencakup area aktual, sedangkan reliabilitas fokus pada pengukuran suatu fenomena yang akan memberikan hasil yang stabil dan konsisten (Taherdoost 2016). Hasil uji validitas dan reliabilitas ini dapat dilihat pada Tabel 1. Berdasarkan Tabel 1 diketahui bahwa semua pertanyaan yang mengukur pengetahuan dan sikap terhadap KP di tempat makan valid pada taraf signifikan $95 \%$. Hasil uji reliabilitas dari semua pertanyaan ini juga menunjukkan nilai lebih besar dari nilai $r$ tabel $(0,2306)$. Hal ini menunjukkan bahwa pertanyaan untuk kuesioner ini valid dan reliabel sebagai alat ukur.

\section{Pengetahuan Keamanan Pangan Responden}

Total responden yang terlibat dalam penelitian ini adalah 454 responden. Setelah melalui proses sortir data diketahui sebanyak 49 responden tidak menjawab pertanyaan dengan lengkap sehingga diambil data 405 responden yang selanjutnya digunakan untuk pengolahan data. Profil responden selengkapnya dapat dilihat pada Gambar 1.

Berdasarkan hasil penelitian seperti yang dapat dilihat pada Gambar 2 menunjukkan bahwa tingkat pendidikan para responden memperlihatkan pengaruh pada tingkat pengetahuan KP. Responden dengan tingkat pendidikan menengah (SMP-SMU) memiliki mayoritas tingkat pengetahuan KP yang kurang baik, sedangkan untuk responden dengan tingkat pendidikan sarjana dan pascasarjana memiliki tingkat pengetahuan KP yang baik (Gambar 2). Berdasarkan tingkat penghasilan per bulan, seperti yang ditunjukkan pada Gambar 3, responden dengan kategori penghasilan rendah yang memiliki tingkat pengetahuan KP yang kurang baik memiliki persentase yang lebih banyak dibandingkan dengan responden berpenghasilan menengah dan tinggi. Berdasarkan total 405 responden, sebagian besar responden, yaitu sebesar 87,7\%, memiliki tingkat pengetahuan KP yang baik.

Berdasarkan hasil uji statistik korelasi Spearman menunjukkan hasil yang signifikan pada taraf 0,01\% pada kategori tingkat pendidikan (nilai korelasi Spearman 0,174) dan penghasilan responden (nilai korelasi Spearman 0,168) dengan hasil skor pengetahuan KP. Hal ini menunjukkan adanya hubungan yang signifikan antara tingkat pendidikan dan tingkat penghasilan dengan tingkat pengetahuan KP karyawan. Hasil uji korelasi Spearman dapat dilihat pada Tabel 2.

Hasil penelitian Sanlier (2009) dan Kilic \& Eryilmaz (2015) menunjukkan terdapat hubungan yang signifikan antara tingkat pengetahuan KP dan umur

Tabel 1 Hasil uji validitas dan reliabilitas kuesioner

\begin{tabular}{ccc}
\hline Daftar pertanyaan & $\begin{array}{c}\text { Hasil uji validitas } \\
(\text { Pearson })\end{array}$ & $\begin{array}{c}\text { Hasil uji reliabilitas } \\
\text { (Alpha Cronbachi) }\end{array}$ \\
\hline P-11 & $0,512^{* *}$ & 0,499 \\
P-12 & $0,435^{* *}$ & 0,525 \\
P-13 -14 & $0,300^{*}$ & 0,525 \\
P-15 & $0,389^{* *}$ & 0,519 \\
P-16 & $0,330^{*}$ & 0,550 \\
P-17 & $0,373^{* *}$ & 0,515 \\
P-18 & $0,740^{* *}$ & 0,402 \\
P-19 & $0,316^{*}$ & 0,592 \\
P-20 & $0,632^{* *}$ & 0,439 \\
S-31 & $0,513^{* *}$ & 0,487 \\
S-32 & $0,624^{* *}$ & 0,461 \\
S-33 & $0,525^{* *}$ & 0,513 \\
S-34 & $0,336^{*}$ & 0,533 \\
S-36 & $0,630^{* *}$ & 0,465 \\
S-37 & $0,719^{* *}$ & 0,425 \\
S-38 & $0,643^{* *}$ & 0,455 \\
S-39 & $0,568^{* *}$ & 0,482 \\
S-40 & $0,626^{* *}$ & 0,467 \\
R & $-0,384^{* *}$ & 0,745
\end{tabular}

Keterangan: $\mathrm{R}$ tabel (koefisien korelasi momen-produk Pearson) dengan $\mathrm{n}=50$ adalah $0,2306,{ }^{*}=$ Signifikan pada taraf 0,05 , ${ }^{* *}=$ Signifikan pada taraf $0,01, \mathrm{P} 11-20=$ Pertanyaan pengetahuan keamanan pangan, dan S31-40 = Pertanyaan sikap terhadap keamanan pangan di tempat makan. 

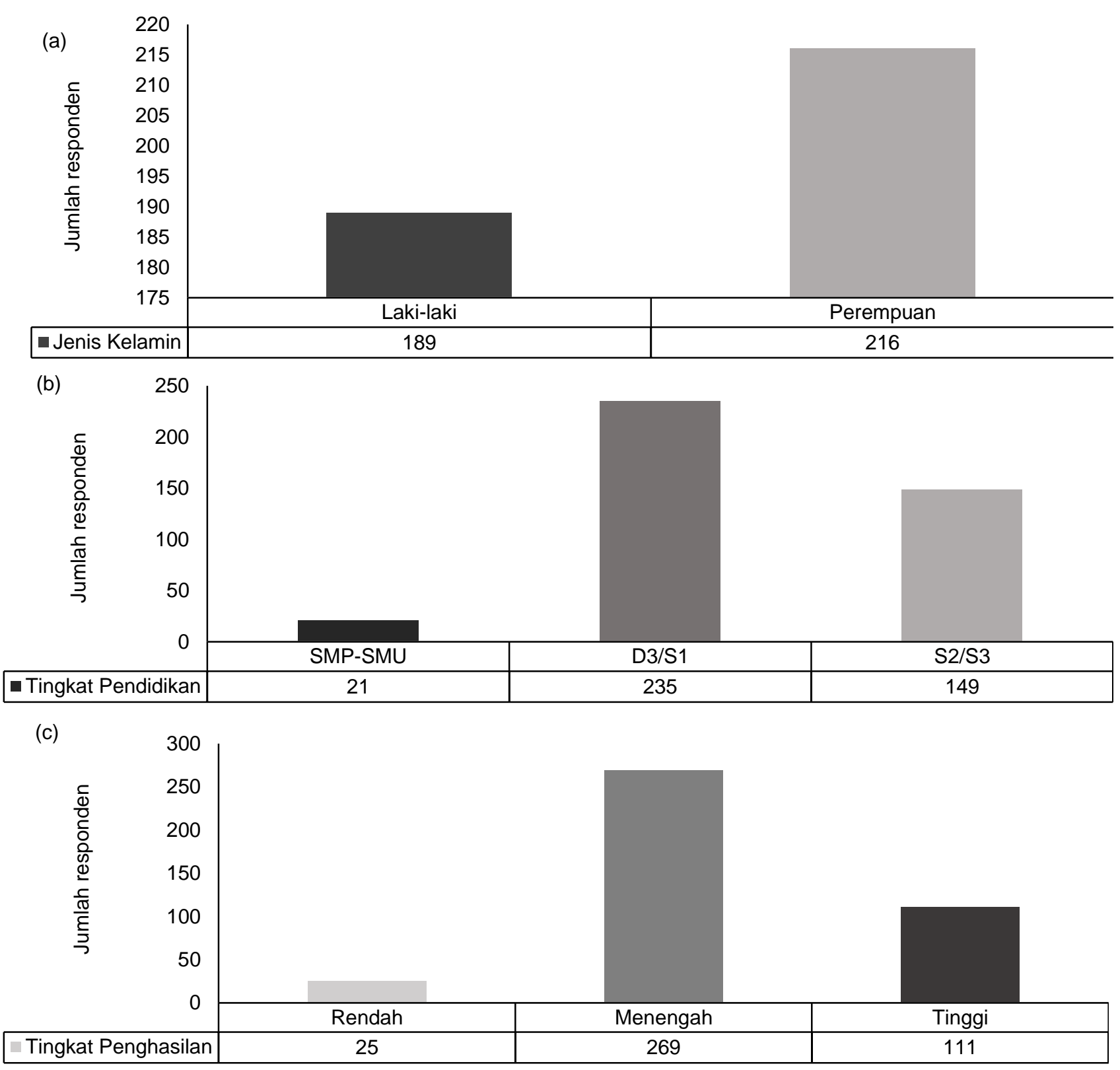

Gambar 1 Profil responden berdasarkan (A) Jenis kelamin laki-laki dan perempuan), (B) Tingkat pendidikan (SMP/SMU, D3/S1 dan S2/S3), dan (C) Tingkat penghasilan (rendah $=<$ Rp3.000.000/bulan; menengah Rp3.500.000Rp15.000.000; dan tinggi $=>$ Rp15.000.000) ( $n=405$ responden).

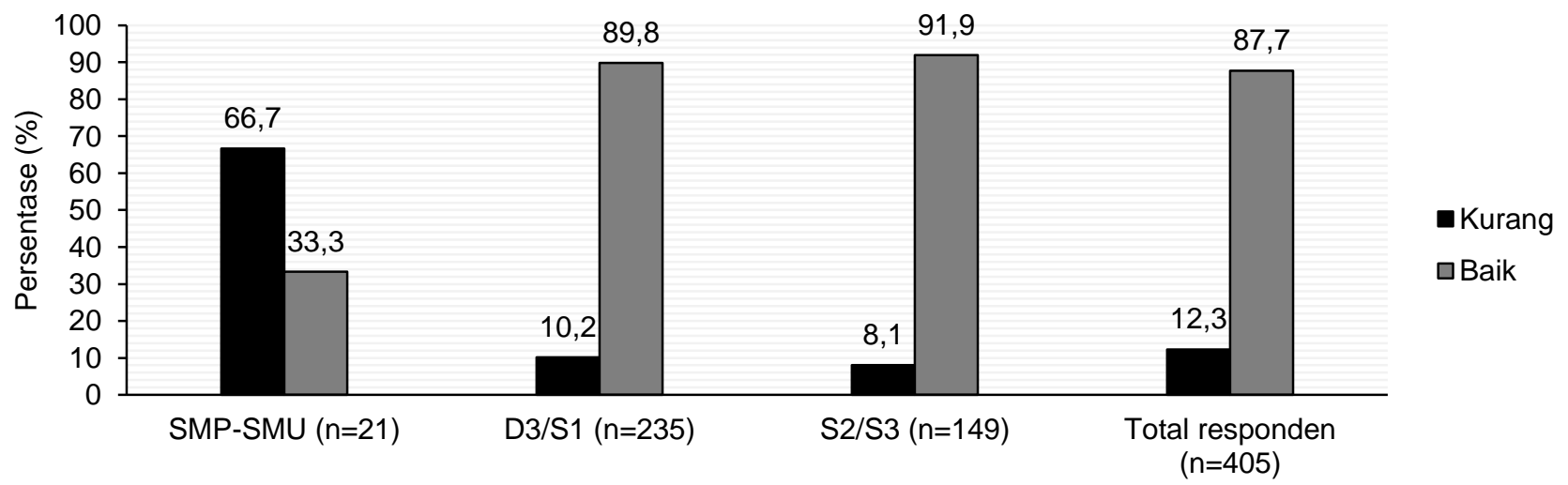

Gambar 2 Tingkat pengetahuan keamanan pangan berdasarkan tingkat pendidikan ( $\mathrm{n}=405$ responden). 


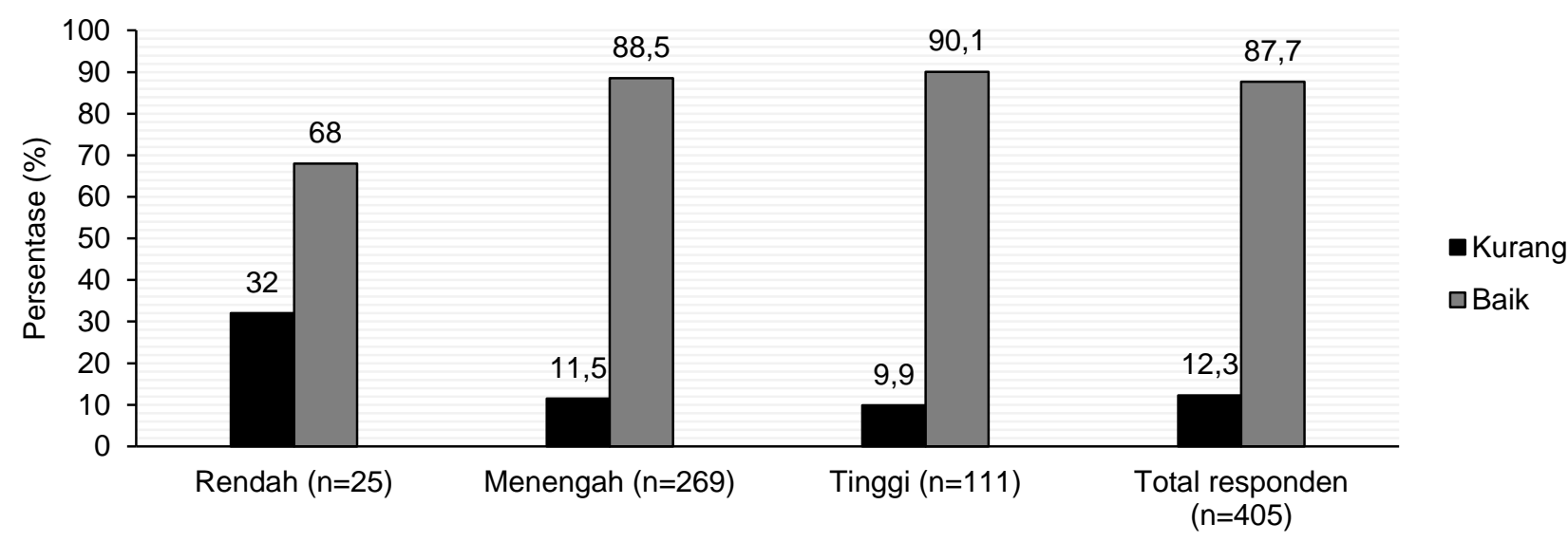

Gambar 3 Tingkat pengetahuan keamanan pangan berdasarkan tingkat penghasilan ( $n=405$ responden).

Tabel 2 Hasil uji korelasi Spearman pengetahuan keamanan pangan $(\mathrm{n}=405)$

\begin{tabular}{lc}
\hline \multicolumn{1}{c}{ Variabel } & Skor pengetahuan \\
\hline Usia & 0,083 \\
Pendidikan & $0,174^{* *}$ \\
Penghasilan & $0,168^{* *}$ \\
\hline
\end{tabular}

Keterangan: ${ }^{* *}$ signifikan pada taraf 0,01 dengan $\mathrm{N}=405$.

serta tingkat pendidikan responden. Semakin tinggi tingkat pendidikan maka semakin tinggi juga tingkat pengetahuan KPnya. Hasil ini berbeda dari hasil penelitian Ma et al. (2019) yang hanya menujukkan hubungan signifikan atara usia dengan tingkat pengetahuan KP, namun tidak menunjukkan hubungan yang signifikan dengan tingkat pendidikan dan penghasilan. Hasil penelitian Elinda-Patra et al. (2020) juga menunjukkan tidak adanya korelasi yang signifikan antara penghasilan dengan tingkat pengetahuan KP responden.

\section{Sikap Terhadap Keamanan Pangan di Tempat Makan di Sekitar Kantor}

Karakteristik responden, seperti tingkat pendidikan dan penghasilan, juga berpengaruh pada skor sikap mereka terhadap KP di tempat makan. Berdasarkan hasil penelitian seperti yang dapat dilihat pada Gambar 4, responden dengan kategori tingkat pendidikan menengah, mayoritas memiliki sikap KP yang kurang. Berdasarkan tingkat penghasilan, seperti yang dapat dilihat pada Gambar 5, responden yang masuk kategori tingkat penghasilan rendah mayoritas memiliki sikap KP di tempat makan yang kurang baik. Berdasarkan total 405 responden yang diteliti, sebagian besar responden atau $64,7 \%$ memiliki sikap $\mathrm{KP}$ yang baik di tempat makan.

Berdasarkan hasil uji korelasi Spearman menunjukkan hasil korelasi yang signifikan pada taraf 0,01 antara sikap KP dengan tingkat pendidikan (nilai korelasi Spearman 0,138) dan tingkat penghasilan responden (nilai korelasi Spearman 0,121). Hal ini menunjukkan adanya hubungan antara tingkat pendidikan dan tingkat penghasilan dengan sikap KP di tempat makan. Hasil uji korelasi Spearman dapat dilihat pada Tabel 3.
Hasil penelitian ini sesuai dengan hasil penelitian Ma et al. (2019) yang menyebutkan bahwa semakin tinggi tingkat pendidikan konsumen semakin baik pula sikap KPnya. Hasil penelitian Elinda-Patra et al. (2020) juga menyebutkan adanya korelasi yang signifikan antara tingkat penghasilan dan sikap KP.

\section{Preferensi Tempat Makan Karyawan}

Selama bekerja di kantor, para karyawan memiliki berbagai pilihan tempat untuk makan siang. Pada umumnya, kantor memiliki kantin yang menyediakan tempat menjual makanan dan minuman yang dikelola oleh manajemen gedung. Beberapa gedung perkantoran bahkan ada juga yang menyewakan area untuk restoran. Di sekitar luar area gedung perkantoran terkadang juga ditemukan warung makan, seperti warung nasi tegal (warteg), warung soto, dan warung nasi padang, yang umumnya dikelola oleh rumah tangga dan harganya terjangkau. Pedagang kaki lima, seperti penjual gerobak siomay atau bakso, bahkan juga masih ditemukan di sekitar kantor. Sebagian karyawan juga ada yang lebih memilih untuk membawa bekal dari rumah untuk makan siang mereka. Berdasarkan hasil penelitian, seperti yang dapat dilihat pada Gambar 6, menunjukkan bahwa sebanyak 37.8\% karyawan memilih kantin, $16.0 \%$ memilih warung makan, dan sebanyak $10,1 \%$ memilih restoran sebagai pilihan utama untuk tempat makan di kantor. Ada berbagai faktor yang menjadi alasan dalam pemilihan tempat makan di kantor, yaitu harga, kebersihan tempat makan, kondisi para penjaja, dan juga rasa makanan. Alasan utama para responden dalam pemilihan tempat makan, yang dapat dilihat pada Gambar 7, adalah faktor rasa dan kualitas makanan sebesar $52 \%$, kebersihan tempat dan peralatan makan sebesar $32 \%$, harga makanan sebesar $11 \%$, dan kebersihan penjaja pangan sebesar $2 \%$.

Berdasarkan hasil uji korelasi Spearman menunjukkan sikap KP di tempat makan memiliki korelasi yang signifikan pada taraf 0,01 dengan preferensi tempat makan (nilai korelasi Spearman 0,147 ) dan menjadi alasan utama pemilihan (nilai korelasi Spearman 0,345), namun tingkat pengetahuan 


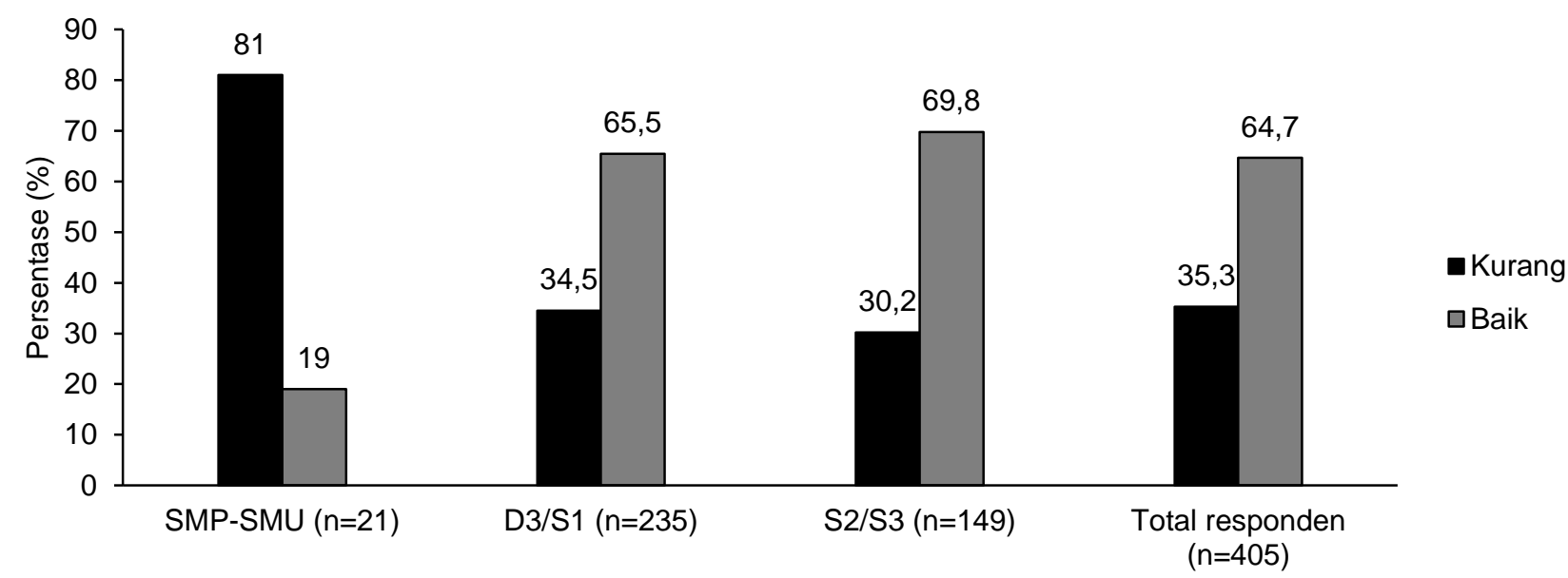

Gambar 4 Sikap terhadap pengetahuan keamanan pangan berdasarkan tingkat pendidikan ( $n=405$ responden) .

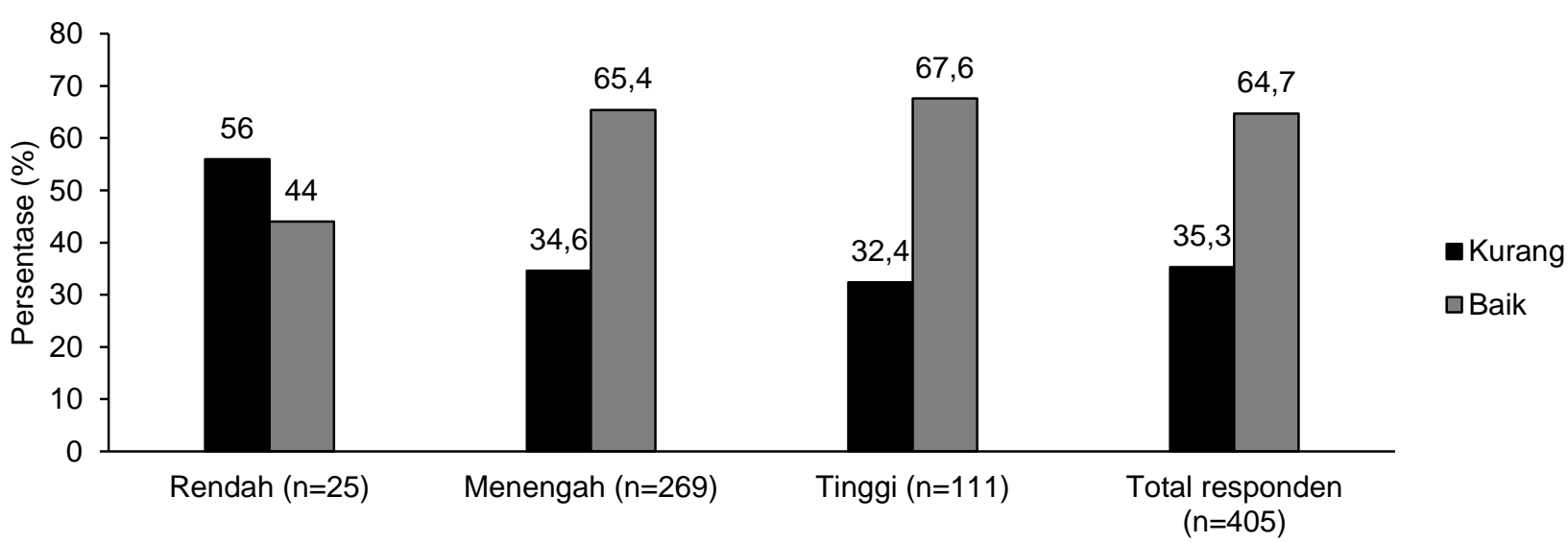

Gambar 5 Sikap terhadap pengetahuan keamanan pangan berdasarkan tingkat penghasilan ( $n=405$ responden).

Tabel 3 Hasil uji korelasi Spearman sikap keamanan pangan $(n=405)$

\begin{tabular}{lc}
\hline \multicolumn{1}{c}{ Variabel } & Skor sikap \\
\hline Pendidikan & $0,138^{\star *}$ \\
Penghasilan & $0,121^{\star}$ \\
\hline
\end{tabular}

Keterangan: ${ }^{\star \star}$ signifikan pada taraf 0,01 dengan $\mathrm{N}=405$.

KP tidak memiliki korelasi yang signifikan dengan preferensi tempat makan. Hal ini menunjukkan bahwa tingkat pengetahuan KP tidak berhubungan dengan preferensi tempat makan, sedangkan sikap terhadap $\mathrm{KP}$ di tempat makan para karyawan memperlihatkan hubungan dengan preferensi tempat makan dan alasan utama pemilihan tempat makan. Hasil uji korelasi Spearman dapat dilihat pada Tabel 4.

Penelitian Henson et al. (2006) menyebutkan bahwa pengetahuan tentang KP memiliki hubungan yang signifikan dengan pemilihan tempat makan. Hasil penelitian Jaini et al. (2015) menyebutkan bahwa kualitas makanan menjadi faktor utama penentu para pelanggan memilih tempat makan. Atinkut et al. (2018) menyebutkan ada beberapa faktor penentu pelanggan dalam memilih tempat makan, seperti KP, harga, dan kemudahan dijangkau.

\section{Peran Media Informasi dan Pemerintah dalam Meningkatkan Kesadaran Masyarakat pada Keamanan Pangan}

Informasi mengenai pentingnya KP dapat diperoleh masyarakat dari berbagai sumber, seperti media sosial, televisi, media cetak, radio, penyuluhan, dan orang terdekat, seperti keluarga, teman, dan tetangga. Data yang lebih lengkap dapat dilihat pada Gambar 8. Berdasarkan hasil survei yang dilakukan, sebagian besar responden $(67,2 \%)$ menilai media sosial sebagai sumber informasi yang efektif untuk menyebarkan informasi mengenai KP kepada masyarakat. Sebagai contoh, informasi KP dapat diperoleh dari website BPOM yang berisi antara lain informasi KP jajanan anak sekolah melalui klubpompi, KP pasar aman, KP untuk keluarga, dan sebagainya. Para responden menilai media sosial sangat efektif dalam penyebaran informasi karena pada saat ini jumlah penduduk Indonesia sebagai pengguna internet sangat tinggi dengan akses informasi yang juga relatif lebih cepat dan mudah didapatkan lewat internet. Data hasil survei nasional tentang penetrasi pengguna internet di tahun 2018 menyebutkan bahwa jumlah pengguna internet Indonesia sebesar 171 juta orang (Kominfo 2019).

Sebagian kecil responden, yaitu sebanyak 3\%, masih menilai bahwa penyuluhan langsung efektif 


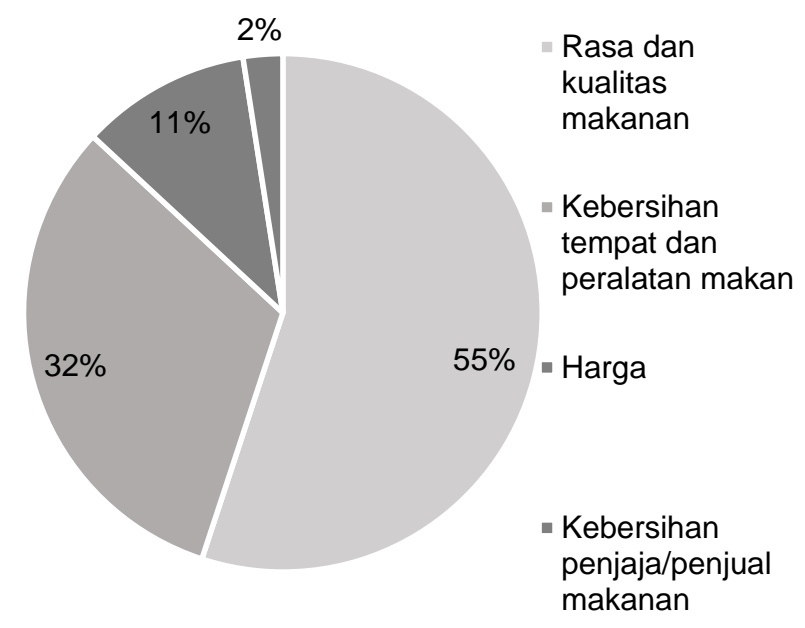

Gambar 6 Preferensi responden $(n=405)$ memilih tempat makan. Pilihan a. Kantin kantor; b. Bawa bekal dari rumah; c. Warung makan; d. Restoran; dan e. Pesan antar

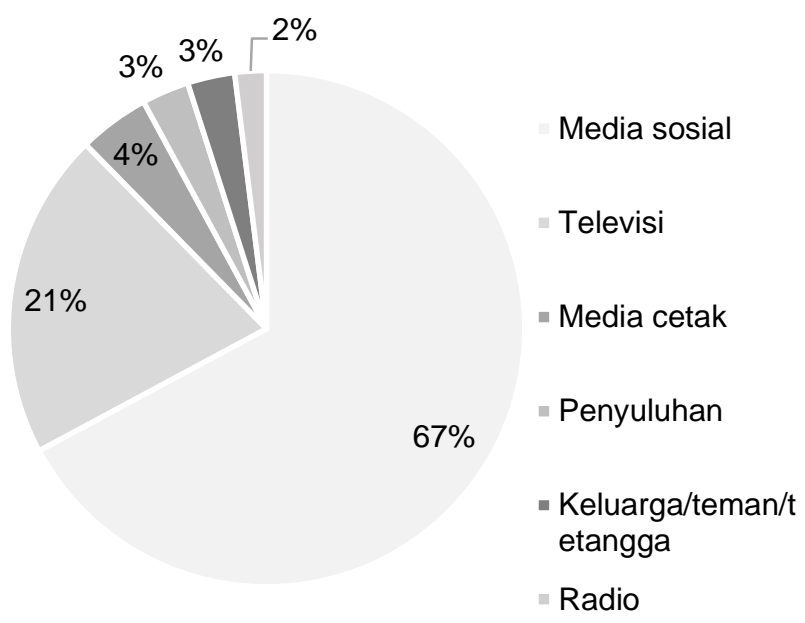

Gambar 7 Alasan utama responden $(n=405)$ memilih tempat makan. Pilihan a. Harga; b. Rasa dan kualitas makanan; c. Kebersihan tempat makan dan peralatan makan, dan d. Kebersihan penjaja/penjual makanan.

Tabel 4 Hasil uji korelasi Spearman pemilihan tempat makan $(n=405)$

\begin{tabular}{lcc}
\hline Variabel & $\begin{array}{c}\text { Preferensi } \\
\text { tempat makan }\end{array}$ & $\begin{array}{c}\text { Alasan utama } \\
\text { memilih tempat } \\
\text { makan }\end{array}$ \\
\hline $\begin{array}{l}\text { Tingkat } \\
\text { pengetahuan KP }\end{array}$ & 0.040 & $0.192^{* \star}$ \\
Sikap terhadap & $0.147^{\star *}$ & $0.345^{\star *}$ \\
KP di tempat \\
makan
\end{tabular}

untuk menyebarkan informasi KP. Hasil penelitian Anggitasari et al. (2014) menyebutkan bahwa penyuluhan bagi siswa sekolah dasar mengenai lima kunci KP (mencuci tangan sebelum mengolah pangan, memisahkan pangan mentah dari pangan matang untuk mencegah kontaminasi silang, memasak secara saksama hingga matang, menyimpan pangan pada suhu aman guna menghindari danger zone, dan terakhir menggunakan air dan bahan baku yang aman) memberikan hasil positif pada tingkat pengetahuan KP. Untuk itu, penyebaran informasi mengenai KP pada saat ini perlu dioptimalkan lagi oleh instansi pemerintah, seperti Kominfo, BPOM, Dinas Kesehatan, maupun oleh para ahli yang peduli KP, dengan cara yang lebih masif di media sosial mulai dari pendidikan dasar, selain penyuluhan KP.

Pemerintah juga sangat berperan dalam hal pengawasan KP, terutama di tempat makan. Dinas Kesehatan Pemprov DKI Jakarta sebagai bagian dari pemerintah daerah bertanggung jawab atas pengawasan di lapangan untuk penerapan standar KP di tempat makan. Peran ini masih dinilai kurang efektif oleh sebagian besar responden, seperti yang dapat dilihat pada Tabel 5 . Sebanyak $60,2 \%$ responden

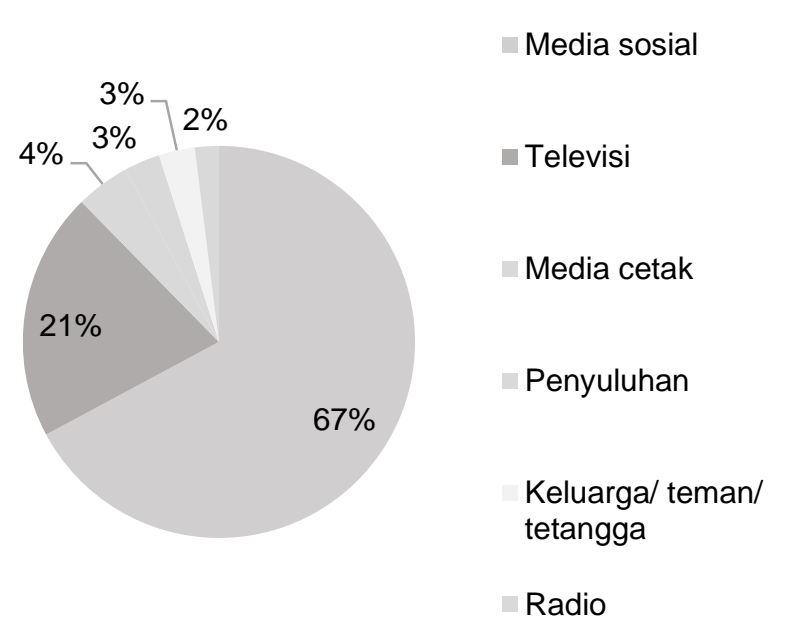

Gambar 8 Efektivitas sumber informasi untuk edukasi keamanan pangan ( $n=405$ responden). Pilihan a. Media sosial; b. Televisi; c. Media cetak; d. Penyuluhan; e. Keluarga/teman/tetangga; dan f. Radio

Tabel 5 Peran pemerintah dalam pengawasan keamanan pangan tempat makan dan edukasi tentang keamanan pangan

\begin{tabular}{lcc}
\hline Peran pemerintah & $\begin{array}{c}\text { Pengawasan } \\
\text { tempat makan } \\
(\%)(n=387)\end{array}$ & $\begin{array}{c}\text { Edukasi (\%) } \\
(\mathrm{n}=380)\end{array}$ \\
\hline Tidak ada & 25,8 & 26,1 \\
Kurang efektif & 60,2 & 58,7 \\
Cukup efektif & 11,1 & 10,6 \\
Sangat efektif & 2,8 & 2,8 \\
\hline
\end{tabular}


menilai peran pemerintah dalam pengawasan KP di tempat makan masih kurang efektif. Selain itu, mayoritas responden, yaitu sebesar $58,7 \%$, menilai pemerintah masih kurang efektif dalam melakukan edukasi dan sosialisasi KP.

\section{KESIMPULAN}

Karakteristik profil karyawan seperti tingkat pendidikan dan tingkat penghasilan berpengaruh pada tingkat pengetahuan dan sikap KP di tempat makan. Sebanyak $87,7 \%$ karyawan kantor memiliki tingkat pengetahuan KP yang baik dan sebanyak 64,7\% karyawan memiliki sikap KP yang baik $(n=405)$. Hasil uji korelasi Spearman menunjukkan tingkat pengetahuan dan sikap KP karyawan berkorelasi dengan tingkat pendidikan dan tingkat penghasilan karyawan.

Preferensi tempat makan yang dipilih oleh karyawan untuk santap siang di kantor adalah kantin sebesar 37,8\%, warung makan sebesar 16,0\%, dan restoran sebesar $10,1 \%$. Faktor rasa dan kualitas pangan menjadi pilihan utama mayoritas karyawan dalam memilih tempat makan diikuti oleh kebersihan tempat makan, harga, dan kebersihan penjaja.

Media informasi yang dinilai cukup efektif untuk menyebarkan informasi mengenai KP menurut karyawan adalah media sosial. Penyebaran informasi tentang KP melalui media sosial perlu dioptimalkan pemerintah agar dapat memberikan informasi yang benar dan terpercaya. Program pengawasan pemerintah, dalam hal ini adalah Dinas kesehatan DKI Jakarta, pada penerapan KP di tempat makan masih perlu ditingkatkan. Peran serta pengelola atau manajemen gedung yang menyediakan tempat makan dan konsumen diharapkan terus ditingkatkan agar KP dapat terus terjamin.

\section{DAFTAR PUSTAKA}

Alimi BA, Oyeyinka AT, Olohungbebe LO. 2016. Socioeconomic characteristics and willingness of consumers to pay for the safety of fura de nunu in Ilorin, Nigeria. Quality Assurance and Safety of Crops \& Foods. 8(1): 81-86. https://doi.org/ 10.3920/QAS2014.0494

Anggitasari A, Rahayu WP, Ratnasari Y. 2014. Pengaruh program keamanan pangan di sekolah terhadap pengetahuan penjaja pangan jajanan dan siswa sekolah dasar. Jurnal Mutu Pangan. 1(2): 151-158

Atinkut HB, Tingwu Y, Gebisa B, Qin S, Assefa K, Yazie B, Melese T, Tadesse S, Mirie T. 2018. Factors influencing consumers' choice of street-foods and fast-foods in China. African Journal of Marketing Management. 10(4): 28-39. https://doi.org/10. 5897/AJMM2018.0572
[BPS DKI Jakarta] Badan Pusat Statistik Provinsi DKI Jakarta. 2020. Provinsi DKI Jakarta dalam angka. Jakarta (ID): BPS Provinsi DKI Jakarta.

[BPOM] Badan Pengawas Obat dan Makanan. 2019. Laporan tahunan BPOM Tahun 2018. Jakarta (ID): Badan POM.

[Dinkes DKI Jakarta] Dinas Kesehatan DKI Jakarta. 2019. Profil kesehatan provinsi DKI Jakarta tahun 2018. Jakarta (ID): Dinkes DKI Jakarta.

Elinda-Patra MW, Dewanti-Hariyadi R, Nurtama, B.2020. Modeling of food safety knowledge, attitude, and behavior characteristics. Food Research 4(4): 1045-1052. https://doi.org/ 10.26656/fr.2017.4(4).375

Henson S, Majowicz S, Masakure O, Sockett P, Jones A, Hart R, Carr D, Knowles L. 2006. Consumer assessment of the safety of restaurants: the role of inspection notices and other Information cues. Journal of Food Safety. 26(2006) 275-301. https://doi.org/10.1111/j.1745-4565.2006.000 49.x

Jaini AB, Ahmad NA. Zaib ZM. 2015. Determinant factors that influence customers' experience in fast food restaurants in Sungai Petani, Kedah. Journal of Entrepreneurship and Business. 3(1): 60-71

[Kemenkes] Kementrian Kesehatan Republik Indonesia. 2016. Peraturan menteri kesehatan Republik Indonesia nomor 48 tahun 2016 tentang standar keselamatan dan kesehatan kerja perkantoran.

[Kominfo] Kementrian Komunikasi dan Informatika. 2019. Laporan Tahunan 2018. Jakarta (ID): Kominfo.

Kilic O, Eryilmaz GA. 2015. Factors affecting consumers'awareness of food safety. Agro Food Industry Hi Tech. 26(3): 43-46

Ma L, Chen H, Yan H, Wu L, Zhang W. 2019. Food safety knowledge, attitudes, and behavior of street food vendors and consumers in Handan, a third tier city in China. BMC Public Health. 19(1128): 13-26

Nurgiyantoro B, Gunawan, Marzuki. 2015. Statistik Terapan untuk Penelitian IImu Sosial: Teori dan Praktik dengan IBM SPSS Statistic 21. Yogyakarta (ID): Gadjah Mada University Press

Pergub DKI Jakarta. 2019. Peraturan Gubernur DKI Jakarta Nomor 121 Tahun 2019 Tentang Upah Minimum Provinsi Tahun 2020.

Prawira IKPY, Wijaya CH, Prangdimurti P. 2016. Korelasi informasi nilai gizi terhadap keputusan pembelian biskuit dan kukis oleh konsumen Jakarta dan sekitarnya. Jurnal Mutu Pangan 3(2):138-144

Rahayu WP. Fardiaz D, Kartika GD, Nababan H, Fanaike R, Puspitasari R. 2016. Estimation of economic loss due to food poisoning outbreaks. 
Food Science and Biotechnology. 25(s): 157-161. DOI 10-1007/s10068-016-113-8.

Riadi E. 2015. Metode Statistika: Parametrik dan Nonparametrik. Tangerang (ID): Pustaka Mandiri.

Sanlier N. 2009. The knowledge and practice of food safety by young and adult consumers. Journal Food Control 20: 538-542. https://doi.org/10.1016/ j.foodcont.2008.08.006

Sevilla CG, Ochave JA, Punsalan TG, Regala BP, Uriarte GG. 2007. Research Methods. Quezon City (PHI) : Rex Printing Company.
Taherdoost H. 2016. Sampling methods in research methodology; how to choose a sampling technique for research. International Journal of Academic Research in Management. 5(2): 18-27. https:// doi.org/10.2139/ssrn.3205035

Totelesi H. 2011. Tinjauan pengetahuan, sikap dan praktik penjamah makanan tentang keamanan pangan dan sanitasi di rumah makan sekitar kampus IPB Darmaga [Skripsi]. Bogor (ID): Institut Pertanian Bogor.

Vyas S, Kushwaha A. 2017. Consumer's perception and knowledge concerning safety of street food services in Pantnagar, India. Journal of Food Safe \& Hygiene. $3(1-2)$ : 34-39. 